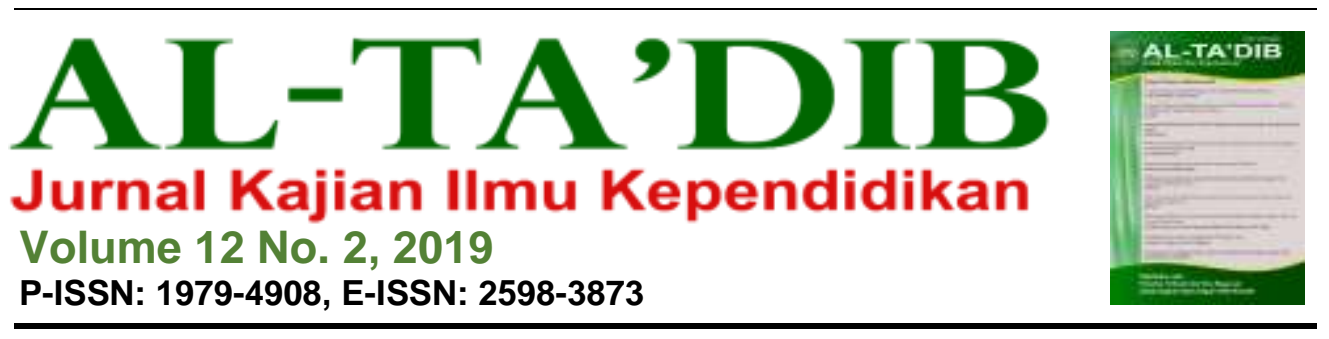

\title{
Pengaruh Internet dan Media Sosial terhadap Kemandirian Belajar dan Hasil Belajar Siswa
}

\section{Dedyerianto $^{1}$}

${ }^{1}$ Institut Agama Islam Negeri Kendari, Indonesia.E-mail: dedyoke1987@gmail.com

\begin{tabular}{l} 
INFORMASI ARTIKEL \\
\hline Kata Kunci: \\
Hasil belajar; internet; \\
kemandirian belajar; media \\
sosial \\
Cara Mensitasi: \\
Dedyerianto. (2019). \\
Pengaruh Internet dan \\
Media Sosial terhadap \\
Kemandirian Belajar dan \\
Hasil Belajar Siswa. Al- \\
Ta'dib:Jurnal Kajian Ilmu \\
Kependidikan, 12(2), 208- \\
225 \\
DOI: \\
http://dx.doi.org/10.31332/ \\
atdbwv12i2.1206 \\
\end{tabular}




\begin{tabular}{l} 
ARTICLE INFO \\
\hline Keywords: \\
Internet; learning \\
autonomy; learning \\
outcome; social media \\
How to cite: \\
Dedyerianto. (2019). \\
Pengaruh Internet dan \\
Media Sosial terhadap \\
Kemandirian Belajar dan \\
Hasil Belajar Siswa. Al- \\
Ta'dib:Jurnal Kajian Ilmu \\
Kependidikan, 12(2), 208- \\
225 \\
DOI: \\
http://dx.doi.org/10.31332/ \\
atdbwv12i2.1206 \\
\hline
\end{tabular}

\begin{abstract}
This study aims to analyze the influence of the internet on the learning autonomy and the learning outcomes, to analyze the influence of social media on the learning autonomy and learning outcomes, and to analyze the influence of learning autonomy on the learning outcomes of students in senior high schools in Kendari. This quantitative research collected data using questionnaire from students in four high schools in Kendari. Saturated sampling was used where all the population is used comprising of 332 respondents. Path analysis was used as the technique of data analysis. The results of data analysis indicate that the internet has an influence on learning autonomy and learning outcomes. As for social media, it does not have any influence on learning autonomy, but it has an influence on learning outcomes. Moreover, learning autonomy does not have any influence on learning outcomes.
\end{abstract}

\section{Pendahuluan}

Pendidikan adalah faktor yang penting dalam pembentukan karakter pribadi manusia. Pendidikan dan ilmu pengetahuan dapat diperoleh bukan hanya dari bangku sekolah saja. Semua faktor bisa dijadikan sebagai sumber dari ilmu pengetahuan. Sejalan dengan perkembangan ilmu pengetahuan serta teknologi di era modern saat ini, pembangunan sumberdaya manusia dituntut memiliki kualitas yang tinggi. Untuk mewujudkan hal tersebut, dapat dilakukan melalui proses pendidikan, baik pendidikan formal di sekolah maupun pendidikan non-formal. Salah satu usaha yang dapat dilakukan adalah dengan meningkatkan mutu lembaga pendidikan formal yang memegang peranan yang sangat penting dalam meningkatkan kualitas sumber daya manusia.

Teknologi selalu berkembang dan mengalami kemajuan sehingga semakin memudahkan manusia untuk beraktivitas, salah satu contoh kemajuan teknologi yang paling terlihat yaitu berkembangnya internet. Munculnya internet ini mempengaruhi berbagai aspek kehidupan manusia, termasuk dalam bidang pendidikan. Belajar menggunakan komputer dan internet adalah paradigma baru yang mulai dikenal masyarakat sekarang ini. Menurut Rodriguez (2005), pembelajaran komputer dan internet memberikan nilai positif dari aspek lain dalam pendidikan. 
Pada kegiatan belajar mengajar di sekolah, tidak bisa dipungkiri bahwa penggunaan internet dan media sosial sudah menjadi trend saat ini. Kini mulai muncul media atau sarana-sarana baru di bidang pendidikan yang diharapkan dapat mempermudah guru dan siswa untuk mengakses informasi yang mereka butuhkan. Internet sebagai wadah belajar siswa dapat membawa akibat yang positif dan juga berdampak negatif untuk pribadi siswa maupun lingkungan pendidikan secara luas. Masuknya internet dalam bidang pendidikan tentunya juga akan membawa dampak bagi para pelajar. Dengan adanya perkembangan teknologi terutama internet, pelajar dapat mengakses materi dimanapun mereka berada.

Berdasarkan hasil survei yang telah dilakukan oleh Asosiasi Penyelengara Jasa Internet Indonesia (APJII) tahun 2016, warga Indonesia merupakan pengguna internet yang sangat tinggi dengan setengah penduduk Indonesia tercatat sebagai pengguna internet. Dari jumlah tersebut sebanyak $75,5 \%$ pengguna internet berusia 10 hingga 24 tahun. Sebanyak 69,8\% adalah pelajar dan $97,4 \%$ situs yang diakses berupa media sosial. Hasil survey tersebut juga mengungkapkan bahwa teknologi internet sangat mempengaruhi kecerdasan pelajar sehingga berdampak pada hasil belajar dan prestasi belajar siswa (Susena \& Lestari, 2014).

Internet atau Interconnection Networking berasal dari bahasa latin "inter" yang artinya "antara". Secara singkat, internet berarti jaringan penghubung atau antara. Internet dapat didefinisikan sebagai hubungan antara beberapa jenis unit komputer beserta jaringan yang tersebar di berbagai dunia yang berbeda sistem operasinya dan juga aplikasinya. Cara menghubungkannya dengan memanfaatkan perkembangan teknologi komunikasi baik telepon maupun satelit dengan menggunakan protokol standar dalam berkomunikasi yaitu Transmission Control/Internet Protocol (TCP/IP) (Shahab, 2000). Internet menyediakan akses untuk layanan telekomunikasi dari sumber daya informasi untuk jutaan pemakainya yang tersebar di seluruh dunia.

Sumber-sumber informasi tanpa batas dan aktual dapat diakses melalui internet dengan sangat cepat. Adanya internet memungkinkan seseorang, misalnya pelajar di Indonesia untuk mengakses perpustakaan di Amerika Serikat dalam bentuk digital library. Internet akan membantu dalam penyelesaian pembelajaran Ilmu Pengetahuan Sosial peserta didik. Tukar menukar informasi atau tanya jawab dengan para ahli dan guru dapat juga dilakukan melalui internet. Saat ini e-learning adalah salah satu literatur dari media pembelajaran online yang bisa diterapkan di sekolah serta dapat didokumentasi dengan baik oleh peserta didik belajar (Shirley, 2001).

Internet sangat bermanfaat bagi akademisi karena internet akan mempermudah pencarian referensi, jurnal, maupun hasil penelitian yang dipublikasikan dalam jumlah yang berlimpah. Peserta didik tidak lagi harus 
mencari buku hanya di perpustakaan sebagai bahan untuk mengerjakan tugas-tugas sekolah. Peserta didik mendapat materi yang dibutuhkan dengan cepat. Selain menghemat tenaga dan biaya dalam mencarinya, materi-materi yang dapat ditemui di internet cenderung lebih up-to-date. Pada intinya, seperti yang disampaikan oleh Liaw, Huang, dan Chen (2006), e-learning adalah teknologi yang berfungsi membina, memberikan, dan memfasilitasi belajar kapan saja dan di mana saja.

Adri (2007) mengungkapkan bahwa internet bermanfaat bagi pengajar dan peserta didik. Bagi pengajar, internet bermanfaat dalam mengembangkan profesinya karena internet dapat membantu meningkatkan pengetahuan, berbagi sumber diantara rekan sejawat, kerjasama dengan para ahli, publikasi informasi secara langsung, mengatur komunikasi secara teratur, dan berpartisipasi dalam forum-forum lokal maupun internasional. Pengajar juga dapat memanfaatkan internet sebagai sumber bahan mengajar dengan mengakses rencana pembelajaran atau silabus online dengan metodologi baru, mengakses materi pembelajaran yang cocok untuk peserta didiknya, serta dapat menyampaikan ide-idenya. Di lain pihak, peserta didik juga dapat menggunakan internet untuk belajar mandiri secara cepat sehingga akan meningkatkan dan memperluas pengetahuan, belajar berinteraksi, dan mengembangkan kemampuannya. Beberapa manfaat internet bagi pendidikan di Indonesia, yaitu akses ke perpustakaan, akses ke pakar, pembelajaran online, layanan informasi akademik, menyediakan fasilitas mesin pencari data, menyediakan fasilitas diskusi, dan fasilitas kerjasama.

Pemanfaatan jaringan internet sebagai sumber dan sarana pembelajaran, dapat diimplementasikan sebagai berikut: a) browsing, merupakan istilah umum yang digunakan bila hendak menjelajahi dunia maya atau web, b) resourcing adalah menjadikan internet sebagai sumber pengajaran, c) searching merupakan proses pencarian sumber pembelajaran guna melengkapi materi yang akan disampaikan kepada peserta didik, dan d) consulting dan communicating (Adri, 2007).

Dalam salah satu penelitian disimpulkan bahwa penggunaan internet dapat dipetakan dalam tiga kategori yaitu, penggunaan fasilitas dalam bentuk web searching, penggunaan fasilitas dalam bentuk email dan penggunaan fasilitas bentuk e-learning. Dari ketiga kategori tersebut, kategori fasilitas web searching adalah yang paling banyak dan dominan digunakan dikalangan pelajar. Hal ini karena internet digunakan oleh mahasiswa dalam menyelesaikan tugas-tugas yang diperoleh dari dosen (Hamka, 2015).

Dengan internet, peserta didik dapat mengakses berbagai informasi dan materi pembelajaran sesuai kebutuhan yang relevan dengan subyek pembelajaran sehingga membantu mempermudah dan mempercepat penyelesaian tugas-tugas pembelajaran. Aktivitas-aktivitas yang dilakukan 
para pengguna internet digolongkan menjadi empat kelompok kepentingan pemanfaatan internet, yaitu: 1) email; 2) aktivitas kesenangan (fun activities) yaitu aktivitas yang sifatnya untuk kesenangan atau hiburan, seperti online untuk bersenang-senang, menonton klip video/audio, mengirim dan menerima pesan singkat, mendengarkan musik, bermain game, atau chatting; 3) kepentingan informasi (information utility) yaitu aktivitas internet untuk mencari informasi, seperti informasi produk, travel, cuaca, film, musik, buku, berita, sekolah, kesehatan, pemerintah, keuangan, pekerjaan, atau politik; 4) transaksi (Transaction), yaitu aktivitas transaksi (jual beli) melalui internet, seperti membeli sesuatu, memesan tiket perjalanan, atau online banking (Horrigan, 2002).

Tidak berbeda jauh dengan pendapat di atas, Buente dan Robbin (2008) lebih lanjut juga melakukan studi atau investigasi tentang trend aktivitas-aktivitas informasi internet warga Amerika antara Maret 2000 hingga November 2004 dan telah berhasil mengklasifikasikan aktivitasaktivitas internet menjadi empat dimensi kepentingan pemanfaatan internet. Dimensi-dimensi ini adalah informasi (information utility), kesenangan (leisure/fun activities), komunikasi (communication), dan transaksi (transaction). Menurut mereka dimensi dimensi tersebut pantas mendapatkan perhatian yang lebih sebab merupakan penyebab dari kebanyakan kepentingan pemanfaatan internet.

Di lingkungan pendidikan, dalam penerapan kurikulum 2013 dan aktivitas proses belajar mengajar, guru dituntut untuk banyak menggunakan internet dan media sosial untuk memperkaya dan memperdalam materi pelajaran. Tujuannya adalah agar kinerja mereka bisa dilaksanakan dengan cepat, akurat dan tepat sehingga dapat meningkatkan produktivitas serta kegiatan-kegiatan pembelajaran yang sudah berbasis elektronik dengan memanfaatkan perkembangan media sosial lebih berkembang (Uno, 2010). Begitu pula halnya dalam menyajikan dan menyiapkan bahan pembelajaran dapat melalui media internet seperti surat elektronik (Udin, 2008).

Media sosial adalah medium di internet yang memungkinkan pengguna merepresentasikan dirinya maupun berinteraksi, bekerja sama, berbagi, berkomunikasi dengan pengguna lain, dan membentuk ikatan sosial secara virtual (Nasrullah, 2015). Karakteristik umum yang dimiliki setiap media sosial yaitu adanya keterbukaan dialog antar para pengguna. Media sosial dapat diubah oleh waktu dan diatur ulang oleh penciptanya, atau dalam beberapa situs tertentu, dapat diubah oleh suatu komunitas. Selain itu media sosial juga menyediakan dan membentuk cara baru dalam berkomunikasi.

Secara garis besar, media sosial dapat diartikan sebagai media online, yang penggunanya (user) terkoneksi melalui internet dan aplikasi berbasis internet untuk berpartisipasi, berbagi, serta menciptakan konten berupa blog, 
forum, wiki, jejaring sosial dan ruang dunia virtual yang didukung dengan perkembangan dunia teknologi yang semakin canggih (Tim Pusat Humas Kementrian Perdagangan RI, 2014).

Dalam dunia pendidikan, penggunaan media sosial juga memiliki dampak positif dan dampak negatif. Dampak positif yang bisa ditimbulkan yaitu dapat mempermudah proses pembelajaran dan bermanfaat terhadap pendidikan akhlak siswa sehingga mereka bisa beradaptasi dengan dunia sosial dan sebagai alat silaturahim. Akan tetapi, media sosial akan berdampak negatif jika disalahgunakan yang bisa berdampak pada siswa jadi menjadi malas, lalai, dan lupa waktu sehingga mengabaikan tugas sekolah (Khairuni, 2016).

Kemandirian belajar merupakan suatu sikap kesiapan dari individu yang mau dan mampu untuk selalu belajar berdasarkan inisiatif sendiri. Hal ini berlangsung dengan atau tanpa bantuan dari pihak lain dalam hal penentuan untuk mencapai tujuan belajar, metode belajar dan evaluasi belajar (Khairuni, 2016). Belajar merupakan proses dalam diri individu yang berinteraksi dengan lingkungan untuk mendapatkan perubahan dalam perilakunya. Menurut Winkel dalam Purwanto (2014), belajar adalah aktifitas mental/psikis yang berlangsung dalam interaksi aktif dengan lingkungan yang menghasilkan perubahan-perubahan dalam pengetahuan, keterampilan dan sikap. Tuntutan belajar tersebut mengharuskan siswa untuk belajar lebih mandiri, disiplin dalam mengatur waktu, dan melaksanakan kegiatan belajar yang lebih terarah dan intensif sehingga memungkinkan siswa untuk tampil produktif, kreatif, dan inovatif. Bekal utama yang dibutuhkan siswa untuk menyesuaikan diri dengan tuntutan tersebut adalah kemampuan dan keterampilan untuk mengatur kegiatan belajar, mengontrol perilaku, dan mengetahui tujuan, arah, serta sumber-sumber yang mendukung belajarnya. Belajar dilakukan untuk mengusahakan adanya perubahan perilaku pada individu yang belajar (Nunuk, 2014). Kemandirian belajar merupakan salah satu faktor intrinsik yang dapat mempengaruhi hasil belajar siswa. Kemandirian belajar adalah aktivitas belajar yang berlangsungnya lebih didorong oleh kemauan sendiri, pilihan sendiri, dan tanggung jawab sendiri (Tirtarahardja \& Sulo, 2005).

Kemandirian belajar adalah perilaku siswa dalam mewujudkan kehendak atau keinginannya secara nyata dengan baik dengan tidak bergantung pada orang lain. Dalam hal ini, siswa mampu melakukan belajar sendiri, dapat menentukan cara belajar efektif, mampu melaksanakan tugas-tugas belajar dengan baik dan mampu untuk melakukan aktivitas belajar secara mandiri. Dari pengertian kemandirian belajar di atas, dapat disimpulkan bahwa kemandirian belajar adalah aspek yang sangat penting dalam dunia pendidikan karena jika siswa 
tidak memiliki kemandirian belajar maka ia akan sulit untuk belajar bertanggungjawab termasuk dalam proses pembelajaran. Selain itu, siswa tidak bisa mengambil keputusannya sendiri dan tidak mempunyai gagasan, ide, dan inisiatif dalam setiap permasalahan yang dihadapi. Hal ini disebabkan karena ketergantungannya kepada orang lain, terlebih kepada orangtua dan teman sebaya dan ia selalu mengandalkan orang lain (Hurlock, 2000).

Kemandirian belajar sangat penting dan harus dimiliki oleh setiap siswa. Menurut teori konstruksvisime, pada saat proses pembelajaran di sekolah, guru tidak dibenarkan memberikan pengetahuan kepada peserta didik begitu saja. Dalam hal ini, siswa yang harus berupaya membangun sendiri pengetahuannya. Ini bertujuan untuk memberikan kesempatan kepada peserta didik menemukan sendiri informasi serta mengaplikasikan ilmu yang telah diperoleh dari guru. Hal ini menunjukkan bahwa makna dari siswa belajar mandiri adalah sikap siswa yang mempunyai kepercayaan diri yang tinggi serta mempunyai inisiatif untuk berusaha mengatasi suatu permasalahan dan bertanggung jawab atas tugas sekolah yang telah dibebankan kepadanya.

Internet, media sosial dan kemandirian belajar diharapkan dapat meningkatkan hasil belajar siswa. Hasil belajar adalah hasil dari suatu hubungan interaksi tindakan belajar dan tindakan dari belajar. Ditinjau dari sisi guru, tindakan mengajar harus diakhiri dengan proses evaluasi hasil belajar, sedangkan dari sisi peserta didik, hasil belajar adalah puncak teratas dari proses belajar. Mengemukakan hasil belajar merupakan kemampuan yang ada pada siswa setelah siswa menerima pengalaman dalam belajarnya (Sudjana, 2014).

Belajar merupakan kegiatan yang terjadi pada semua orang tanpa mengenal batas usia dan berlangsung seumur hidup. Belajar adalah proses seseorang dalam memperoleh berbagai kecakapan, keterampilan dan sikap. Belajar sebagai aktivitas mental (psikis), berlangsung dalam interaksi aktif dengan lingkungannya yang menghasilkan perubahan sikap. Perubahan itu bersifat relatif, konstan dan berbekas serta harus berfungsi dalam kehidupan anak baik segi intelektual maupun segi sosial, emosional, etika dan sebagainya (Warti, 2016).

Hasil belajar juga dapat dijelaskan dari memahami dua kata pembentuknya, yaitu "hasil" dan "belajar". Hasil mengarah pada suatu pencapaian dari proses melakukan suatu aktivitas atau proses yang mengakibatkan perubahan input secara fungsional. Sedangkan belajar dilakukan untuk mengusahakan adanya perubahan prilaku dari seseorang yang belajar (Purwanto, 2011). Hasil dari proses belajar juga merupakan perubahan semua perilaku secara keseluruhan, bukan hanya ada pada satu aspek saja. Perubahan hasil belajar ini juga merupakan perubahan perilaku 
yang diperoleh para peserta didik setelah mengalami dan mengikuti kegiatan belajar. Hasil dari belajar tersebut bisa saja berupa perubahan dalam bentuk aspek kognitif, aspek afektif dan juga aspek psikomotorik (Purwanto, 2011). Hasil belajar yang telah diperoleh dan dicapai oleh para peserta didik adalah hasil dari interaksi antara beberapa faktor yang dapat mempengaruhi, baik itu faktor internal yang meliputi minat, kecerdasan dan juga perhatian, kondisi fisik atau kesehatan. Kondisi yang mempengaruhi hasil belajar meliputi sekolah, keluarga, dan masyarakat (Susanto, 2014).

Penelitian ini dilakukan untuk mengkaji kemandirian belajar siswa dalam meningkatkan hasil belajar dengan bantuan internet sebagai media belajar tambahan dan media sosial sebagai media diskusi siswa dalam proses pembelajaran.

\section{Metode Penelitian}

Penelitian ini merupakan penelitian explanatory. Penelitian ini menggunakan metode survey yang ditujukan untuk memberikan penjelasan mengenai fenomena yang diteliti dan hubungan antar variabel. Data dikumpulkan menggunakan angket yang dibagikan kepasa populasi siswa IPA kelas XI di empat SMA di Kota Kendari. Teknik penarikan sampel menggunakan sampling jenuh dimana semua populasi digunakan sebagai sampel yang terdiri atas 332 responden. Penelitian ini menggunakan dua metode analisis yaitu metode statistik deskriptif dan inferensial. Analisis secara deskriptif digunakan untuk mengetahui karakteristik dari responden terhadap indikator-indikator setiap variabel penelitian. Data deskriptif yang diperoleh untuk setiap indikator ini dinyatakan dalam nilai dan rata-rata. Analisis secara deskriptif juga ditujukan untuk pernyataan yang berkaitan dengan variabel penelitian. Sedangkan secara inferensial, dilakukan untuk menguji hipotesis dan menghasilkan suatu model yang layak (fit). Teknik analisis dalam penelitian ini penggunakan path analysis (analisis jalur) yang digunakan untuk mengetahui dan menganalisis pengaruh variabel-variabel independen terhadap variabelvariabel dependen.

\section{Hasil dan Pembahasan}

\subsection{Deskripsi Variabel Penelitian}

Deskripsi variabel penelitian bertujuan untuk menginterprestasikan distribusi frekuensi dalam lima kategori dengan menggunakan skala Likert. Dalam memberikan makna penilaian secara empiris, variabel penelitian ini 
mengadopsi prinsip pembobotan yang digunakan dan dimodifikasi oleh Noermijati (2008) dari beberapa sumber referensi. Nilai rata-rata pembobotan atau nilai skor jawaban yang diperoleh diklasifikasikan ke dalam rentang skala kategori nilai yang disajikan dalam Tabel 1 sebagai berikut.

Tabel 1 Penentuan kategori rata-rata skor pernyataan responden dan makna penilaian secara deskriptif

\begin{tabular}{cccc}
\hline No & $\begin{array}{c}\text { Nilai Rata-Rata Skor } \\
\text { Jawaban }\end{array}$ & Makna Kategori/Interpretasi & $\begin{array}{c}\text { Nilai } \\
\text { Skor }\end{array}$ \\
\hline 1 & $1,00-1,80$ & Sangat Rendah/Tidak Baik & 1 \\
2 & $1,81-2,60$ & Rendah/Kurang Baik & 2 \\
3 & $2,61-3,40$ & Cikup Tinggi/Cukup Baik & 3 \\
4 & $3,41-3,20$ & Tinggi/Baik & 4 \\
5 & $4,21-5,00$ & Sangat Tinggi/Sangat Baik & 5 \\
\hline
\end{tabular}

Distribusi frekuensi tersebut diperoleh dari hasil skor jawaban responden terhadap item pernyataan pada empat variabel yaitu internet (media belajar), sosial media, kemandirian belajar dan hasil belajar. Uraian dari analisis statistik deskiptif dari masing-masing variabel adalah sebagai berikut.

\section{Internet}

Hasil penelitian menunjukkan bahwa tanggapan responden terhadap pemanfaatan internet sudah baik. Hal ini terlihat dari rata-rata persepsi responden terhadap internet sebagai media belajar adalah 3,34 yang berarti sudah baik dan sesuai jika dibandingkan dengan pembobotan kategori rata-rata skor pernyataan responden pada Tabel 1. Dari persepsi responden tersebut tampak bahwa nilai indikator Fungsi Internet mendapat perhatian yang lebih kuat dilihat dari rata-ratanya sebesar 3,51 dibandingkan indikator Intensitas Waktu Penggunaan Internet sebesar 3,45 dan indikator Jenis Layanan yang Diakses sebesar 3,05.

Dari persepsi responden tampak pula bahwa nilai terendah ada pada indikator Jenis Layanan yang Diakses sebesar 3,05. Hal ini dikarenakan siswa belum sepenuhnya menggunakan layanan internet secara baik dan masih banyak siswa yang belum menguasai dan menggunakan fasilitas internet dengan bijak. Hal yang perlu diperhatikan dengan baik adalah bagaimana siswa dapat meningkatkan kemandirian belajarnya dengan memanfaatkan fasilitas internet sebagai media belajar tambahan selain tatap muka di kelas. 


\section{Media Sosial}

Hasil penelitian menunjukkan bahwa pemanfaatan media sosial menurut tanggapan responden sudah baik. Hal ini terlihat dari rata-rata persepsi responden terhadap sosial media adalah 2,98 yang berarti cukup baik dan sesuai jika dibandingkan dengan pembobotan kategori rata-rata skor pernyataan responden pada Tabel 1 . Dari persepsi responden tersebut tampak bahwa nilai indikator Intensitas Mengakses Media Sosial mendapat perhatian yang lebih kuat dilihat dari rata-ratanya sebesar 3,20 dibandingkan indikator Ketika Sedang Online Facebook Saya Sering, sebesar 2,20. Indikator Ketika Sedang Online Instagram Saya Sering, sebesar 3,00 dan indikator Ketika Saya Sedang Online Whatsapp Saya Sering, sebesar 3,16.

Dari persepsi responden tampak pula bahwa nilai terendah ada pada indikator Sering, sebesar 2,20 untuk item Ketika Sedang Online Fb Saya Sering. Hal ini dikarenakan siswa sudah banyak yang tidak menggunakan facebook untuk berkomunikasi online. Siswa cendurung lebih banyak menggunakan sosial media WhatsApp. Hal yang perlu diperhatikan dengan baik adalah bagaimana siswa dapat meningkatkan kemandirian belajarnya dengan memanfaatkan fasilitas media sosial sebagai sarana belajar dan berdiskusi.

\section{Kemandirian Belajar}

Tanggapan responden terhadap kemandirian belajar adalah "cukup baik". Hal ini terlihat dari rata-rata persepsi responden terhadap kemandirian belajar adalah 2,91 yang berarti cukup baik dan sesuai jika dibandingkan dengan pembobotan kategori rata-rata skor pernyataan responden pada tabel 1. Dari persepsi responden tersebut tampak bahwa nilai indikator "saya selalu menyiapkan buku-buku alat tulis menulis atau peralatan belajar lain yang dibutuhkan sebelum belajar (disimbolkan Y1.1.1)" dan "setiap ada ulangan yang sulit, saya mencontek dari buku atau melirik pekerjaan teman (disimbolkan Y1.1.11)" mendapat perhatian yang lebih kuat dilihat dari rata-ratanya sebesar 3.96 dibandingkan indikator lainnya.

Dari persepsi responden tampak pula bahwa nilai terendah ada pada indikator "jika materi pelajaran belum saya pahami saya berusaha mencari buku-buku perpustakaan untuk membantu memahami" (disimbolkan Y1.1.6) dan "apabila guru sedang menerangkan saya mengobrol dengan teman sebangku (disimbolkan Y1.1.12) sebesar 2.42. Dari sini nampak bahwa, berdasarkan analisa pada sampel, kemandirian belajar siswa sudah cukup baik, dimana siswa cenderung berusaha 
menyelesaikan tugas belajar sendiri, berusaha belajar lebih giat lagi, mencatat hal-hal yang penting saat proses pembelajaran serta memikirkan solusi sendiri saat mengalami masalah belajar.

\section{Hasil Belajar Matematika}

Hasil penelitian menunjukkan bahwa hasil belajar yang diperoleh siswa cukup baik. Dari semua soal (24 butir soal) yang diberikan, persentase siswa berhasil menjawab dengan benar adalah 41,06 \%. Dari jawaban responden tersebut tampak bahwa nilai indikator soal nomor 6 atau (Y2.1.6) adalah jenis soal yang paling banyak dijawab benar oleh siswa dengan nilai rata-rata sebesar 57\% dari 332 siswa, dibandingkan indikator lainnya. Selain itu, tampak pula bahwa nilai terendah ada pada indikator soal nomor 24 atau (Y2.1.24) sebesar 21\% dari 332 siswa. Akan tetapi, secara keseluruhan ada $43,22 \%$ siswa masih memberikan jawaban yang tergolong kurang baik dan ada 56,78\% siswa yang menjawab salah. Hal ini dikarenakan banyak siswa yang telah lupa bagaimana cara menyelesaikan soal yang telah dipelajari di kelas XI dan siswa tidak mengulang materi yang telah diberikan oleh guru.

\subsection{Hasil Pengujian Hipotesis Penelitian}

Hasil pengujian hipotesis dengan analisis jalur membuktikan bahwa tiga hipotesis dinyatakan signifikan dan dua dinyatakan tidak signifikan. Pengujian hipotesis dilakukan dengan melihat nilai koefisien standard, nilai signifikan uji p-value dan tanda hubungan masing-masing variabel independen terhadap variabel dependennya secara parsial.

Tabel 2 Hasil pengujian hipotesis

\begin{tabular}{lllccc}
\hline $\begin{array}{l}\text { Variabel } \\
\text { Independen }\end{array}$ & $\begin{array}{l}\text { Variabel } \\
\text { Intervening }\end{array}$ & $\begin{array}{l}\text { Variabel } \\
\text { Dependen }\end{array}$ & $\begin{array}{c}\text { Koefisien } \\
\text { Jalur } \\
(\text { Direct })\end{array}$ & p-value & $\begin{array}{c}\text { Ket } \\
(\alpha=0.05)\end{array}$ \\
\hline $\begin{array}{l}\text { Internet (Media } \\
\text { Belajar) (X1) }\end{array}$ & $\begin{array}{l}\text { Kemandirian } \\
\text { Belajar (Y1) }\end{array}$ & $\begin{array}{l}\text { Hasil Belajar } \\
(\text { Y2) }\end{array}$ & 0.278 & 0.000 & Sig \\
Kemandirian & 0.002 & 0.967 & Tdk Sig \\
Sosial Media (X2) & - & $\begin{array}{l}\text { Belajar (Y1) } \\
\text { Hasil Belajar } \\
\text { Kepuasan }\end{array}$ & -0.163 & 0.002 & Sig \\
$\begin{array}{l}\text { Kemandirian } \\
\text { Belajar (Y1) }\end{array}$ & - & $\begin{array}{l}\text { Hasil Belajar } \\
\text { (Y2) }\end{array}$ & -0.091 & 0.111 & Tdk sig \\
\hline
\end{tabular}


Model pengaruh antara variabel dependen dan variabel independen disajikan pada gambar dibawah ini:

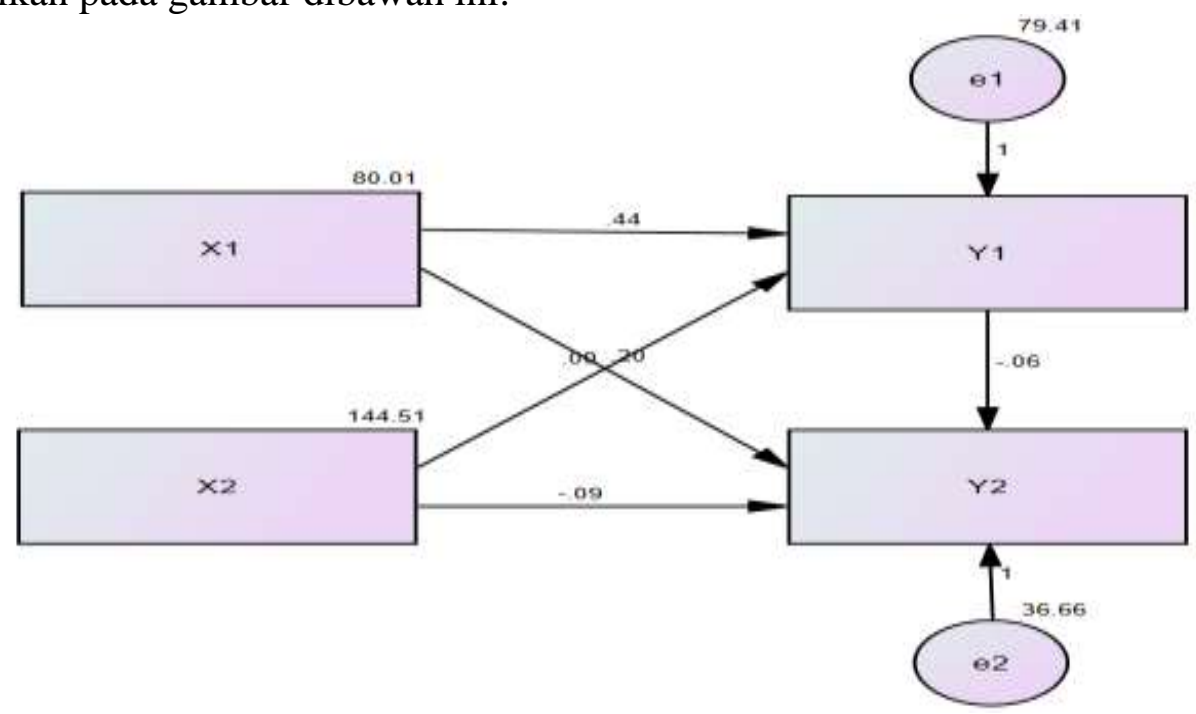

Gambar 1 Desain Penelitian

Hipotesis 1: Internet berpengaruh positif dan signifikan terhadap kemandirian belajar

Pengujian hipotesis dengan pendekatan analisis jalur menghasilkan koefisien jalur pengaruh langsung internet terhadap kemandirian belajar dengan nilai 0,402 dan $p$-value 0,000. Karena $p$-value $<0,05$ maka variabel internet sebagai media belajar mempunyai pengaruh yang signifikan terhadap kemandirian belajar dengan kontribusi efek sebesar 0,402 atau $(40 \%)$ yang berarti bahwa ada kecenderungan sebesar $40 \%$ meningkatnya kemandirian belajar karena adanya internet sebagai media belajar yang baik. Penggunaan internet digunakan oleh siswa sebagai media belajar selain tatap muka di depan kelas.

Hipotesis 2: Internet (media belajar) berpengaruh positif dan signifikan terhadap hasil belajar siswa

Pengujian hipotesis dengan pendekatan analisis jalur menghasilkan koefisien jalur berpengaruh langsung internet sebagai media belajar terhadap hasil belajar siswa dengan nilai 0,278 dengan $p$-value $=0,000$. Karena $p$-value $<0,05$ maka variabel internet sebagai media belajar mempunyai pengaruh yang signifikan terhadap hasil belajar siswa dengan kontribusi efek sebesar 0,278 atau (27\%)yang berarti bahwa ada kecenderungan sebesar $27 \%$ meningkatnya hasil belajar siswa karena adanya internet sebagai media belajar. 
Hipotesis 3: Media sosial berpengaruh positif dan signifikan terhadap kemandirian belajar siswa

Pengujian hipotesis dengan pendekatan analisis jalur menghasilkan koefisien jalur pengaruh langsung media sosial terhadap kemandirian belajar dengan nilai 0,002 dengan $p$-value $=0,967$. Karena $p$-value $>$ 0,05 maka variabel sosial media tidak memiliki pengaruh yang signifikan terhadap kemandirian belajar dengan kontribusi efek sebesar 0,002. Ini juga berarti bahwa siswa dapat belajar dengan mandiri tanpa dipengaruhi penggunaan berbagai macam media komunikasi online.

Hipotesis 4: Sosial media berpengaruh positif dan signifikan terhadap hasil belajar siswa

Pengujian hipotesis dengan pendekatan analisis jalur menghasilkan koefisien jalur pengaruh langsung sosial media terhadap hasil belajar siswa dengan nilai $-0,163$ dengan $p$-value $=0,002$. Karena $p$-value $<0,05$ maka variabel media sosial mempunyai pengaruh yang signifikan terhadap hasil belajar. Ini disebabkan karena media sosial sering dijadikan media sharing dan media berbagi informasi materi pelajaran.

Hipotesis 5: Kemandirian belajar berpengaruh positif dan signifikan terhadap hasil belajar

Pengujian hipotesis dengan pendekatan analisis jalur menghasilkan koefisien jalur pengaruh langsung kemandirian belajar terhadap hasil belajar dengan nilai $-0,091$ dengan $p$-value $=0,111$. Karena $0,111>0,05$ maka variabel kemandirian belajar mempunyai pengaruh yang negatif dan tidak signifikan terhadap hasil belajar siswa dengan kontribusi efek sebesar -0,091 yang berarti bahwa kemandirian belajar tidak signifikan memengaruhi hasil belajar siswa.

Dari hasil analisis model jalur di atas dapat diketahui bahwa pengaruh langsung internet (media belajar) dan sosial media terhadap kemandirian belajar dan hasil belajar dapat dijelaskan sebagai berikut. Pertama, analisis pengaruh langsung internet sebagai media belajar terhadap kemandirian belajar menghasilkan nilai koefisien jalur positif dan signifikan. Hal ini mengindikasikan bahwa internet sebagai media belajar mempunyai hubungan yang searah dan berpengaruh terhadap kemandirian belajar siswa pada SMA di Kota Kendari. Hal ini sejalan dengan pendapat Rodriguez (2005) dalam penelitiannya yang mengemukakan bahwa pembelajaran dengan media komputer dan internet memberikan nilai positif dari aspek lain dalam pendidikan. Belajar menggunakan komputer dan internet adalah paradigma baru yang mulai dikenal masyarakat, tak terkecuali siswa. 
Dengan adanya fasilitas internet yang dimanfaatkan oleh siswa sebagai sumber belajar, maka siswa mendapatkan media belajar yang baru dan ilmu pengetahuan yang lebih cepat. Siswa dapat memanfaatkan internet sebagai bahan belajar mandiri dengan tujuan meningkatkan keilmuan siswa terkait pemahaman matematika. Peserta didik tidak lagi mencari buku diperpustakaan sebagaibahan untuk mengerjakan tugas-tugas matapelajaran matematika. Peserta didik mendapatkan materi yang dibutuhkan dengan cepat dengan menggunakan internet (Rodriguez, 2005). Hal ini sesuai dengan pendapat Hardjito (2018) bahwa internet dapat digunakan dalam mendukung pembelajaran di kelas karena memiliki karateristik yang khas, yaitu sebagai media komunikasi dan media massa yang memungkinkan terjadinya komunikasi one-to-one maupun one-to-many, memiliki sifat interaktif dan memungkinkan terjadinya komunikasi secara sinkron maupun tertunda. Berdasarkan pemaparan tersebut maka dapat disimpulkan bahwa internet dapat dijadikan sebagai media pembelajaran elektronik yang mendukung kemandirian belajar siswa.

Kedua, hasil analisis pengaruh langsung internet sebagai media belajar terhadap hasil belajar siswa menunjukkan nilai koefisien jalur positif dan signifikan. Hal ini memastikan bahwa internet sebagai media belajar mempunyai hubungan yang searah dan berpengaruh terhadap hasil belajar siswa pada SMA di Kota Kendari. Hasil penelitian ini mengungkapkan bahwa penggunaan media internet berjalan baik dan sangat membantu dalam belajar siswa. Hasil penelitian ini senada dengan pendapat Ahira (2011) menegaskan bahwa penggunaan media internet sebagai media belajar sangat membantu para akademisi dalam belajar.

Ketiga, hasil belajar yang diperoleh dari empat sekolah SMA di Kota Kendari pada mata pelajaran matematika menunjukkan bahwa responden mendapatkan nilai baik berdasarkan kontribusi efek sebesar $27 \%$. Hal ini sesuai dengan pendapat Ahira (2011) bahwa internet memberikan informasi pendidikan yang sangat banyak dan luas serta sangat berguna bagi siswa dalam menunjang proses pembelajaran mereka. Semakin sering dan intens siswa menggunakan media internet untuk dalam proses belajar maka hasil belajarnya akan meningkat.

Hasil analisis pengaruh langsung media sosial terhadap kemandirian belajar siswa tidak signifikan. Hal ini menunjukkan bahwa media sosial mempunyai hubungan yang positif dan searah namun tidak berpengaruh terhadap kemandirian belajar siswa pada SMA di Kota Kendari. Ini berarti bahwa pengunaan media sosial siswa, termaksud kekerapan mengakses media sosial memiliki pengaruh yang sangat kecil terhadap kemandirian belajar siswa dengan kontribusi efek sebesar 0,2\%. Dari hasil analisis, hal ini berdampak baik karena intensitas penggunaan sosial media tidak mempengaruhi kemandirian belajar siswa. Hasil ini sesuai dengan harapan 
pihak sekolah saat survey lapangan sebelum dimulainya penelitian. Pihak sekolah mengharapkan intensitas penggunaan media sosial yang sangat tinggi tidak mempengaruhi kemandirian belajar siswa.

Keempat, hasil analisis pengaruh langsung sosial media terhadap hasil belajar menunjukkan nilai koefisien jalur negatif dan signifikan. Hal ini mengindikasikan intensitas penggunaan sosial media yang sangat tinggi akan berdampak buruk untuk hasil belajar siswa. Pengaruh ini memiliki hubungan yang tidak searah dan berpengaruh negatif terhadap hasil belajar siswa pada SMA di Kota Kendari. Dalam proses kegiatan belajar mengajar di sekolah, siswa cenderung menggunakan sosial media saat belajar/ujian berlangsung. Seperti yang dikemukakan oleh Wijaya (2018), penggunaan sosial media dalam proses belajar sangat berdampak negatif dan memberikan pengaruh yang signifikan. Hasil belajar siswa cenderung rendah akibat tingginya intensitas penggunaan sosial media sehingga waktu belajar menjadi berkurang.

Kelima, hasil analisis pengaruh langsung kemandirian belajar terhadap hasil belajar siswa memiliki pengaruh yang tidak signifikan. Hal ini menunjukan bahwa kemandirian belajar mempunyai hubungan yang negatif, tidak searah dan tidak berpengaruh terhadap hasil belajar siswa pada SMA di Kota Kendari. Salah satu penyebab keadaan ini adalah kurangnya kesadaran siswa untuk belajar mandiri selain tatap muka di sekolah.

\section{Kesimpulan}

Dari hasil pembahasan penelitian ini diperoleh kesimpulan bahwa internet sebagai media belajar, media sosial dan kemandirian belajar berperan terhadap hasil belajar siswa. Internet sebagai media belajar berpengaruh positif dan signifikan terhadap kemandirian belajar siswa. Sebaliknya, media sosial berpengaruh namun tidak menunjukkan pengaruh yang signifikan terhadap kemandirian belajar siswa. Serta, kemandirian belajar siswa berpengaruh negatif terhadap hasil belajar siswa.

\section{Daftar Pustaka}

Adri, M. (2007). Pemanfaatan internet sebagai sumber pembelajaran. Makalah dalam rangka Semiloka Pengembangan Model Pembelajaran Berbasis Teknologi Informasi. Padang: Fakultas Teknik Universitas Negeri Padang. 
Ahira, A. (2011). Pengaruh internet terhadap prestasi belajar siswa. Diakses dari http://annaahira.com. tanggal 20 September 2018.

Asosiasi Penyelenggara Jasa Internet Indonesia (APJII). (2016). Infografis penetrasi dan perilaku penggunaan internet Indonesia: Survei 2016. Diakses dari www.apjii.org.com. tanggal 13 Desember 2017.

Buente, W., \& Robbin, A. (2008). Trends in internet information behavior: 2000 - 2004. Journal of the American Society for Information Science, 59(11), 1743-1760.

Hamka, H. (2015). Penggunaan internet sebagai media pembelajaran pada mahasiswa IAIN Palu. HUNAFA: Jurnal Studia Islamika, 12(1), 95119.

Hardjito. (2018). Internet untuk pembelajaran (online). Diakses dari http://www.pustekom.go.id/teknodik/t10/10-3.htm. tanggal 12 September 2018.

Horrigan, J. B. (2002). New internet users: What they do online, what they don't, and implications for the net's future. Pew Internet and American Life Project.

Hurlock, E. B. (2000). Psikologi perkembangan. Jakarta: Erlangga.

Khairuni, N. (2016). Dampak positif dan dampak negatif sosial media terhadap pendidikan akhlak anak. Jurnal Edukasi: Jurnal Bimbingan Konseling, 2(1), 91-106.

Liaw, A., Huang, \& Chen. (2006). Surveying instructor and learner attitudes toward e-learning. Taiwan: Department of Computer Science \& Information Engineering National Central University.

Nasrullah, R. (2015). Media sosial perspektif komunikasi, budaya, dan sosioteknologi. Jakarta: Simbiosa Rekatama Media.

Noermijati. (2008). Aktualisasi teori Herzberq: Suatu kajian terhadap kepuasan kerja dan kinerja spiritual manajer operasional. Disertasi tidak Dipublikasikan. Universitas Brawijaya, Malang. 
Nunuk, M. (2014). Pengaruh kemandirian belajar dan sarana prasarana pembelajaran terhadap hasil belajar praktik di SMK Negeri 2 Tuban. Jurnal Ekonomi Pendidikan dan Kewirausahaan, 2(1), 103-115.

Purwanto, N. (2011). Evaluasi hasil belajar. Yogyakarta: Pustaka Pelajar.

Rodriguez, P. (2005). An instructional model for web-based e-learning education with a blended learning process approach, Journal of Educational Technology, 36(2), 217-235.

Shahab, A. (2000). Internet bagi profesi kedokteran. Jakarta: EGC.

Shirley, A. (2001). Bridging the digital divide. Paper presented at Conference Technological Demands on Women in Higher Education, South Africa.

Sudjana, N. (2014). Penilaian hasil proses belajar mengajar. Bandung: Remaja Rosdakarya.

Susanto, A. (2014). Teori belajar dan pembelajaran di sekolah dasar. Jakarta: Kencana Prenadamedia Group.

Susena, E., \& Lestari, D. A. (2014). Dampak penggunaan internet terhadap kecerdasan pelajar Sekolah Menengah Atas (SMA) di daerah pedesaan dalam rangka peningkatan kualitas pendidikan di daerah pedesaan. Jurnal Sainstech Politeknik Indonesia Surakarata, 1(2).

Tim Pusat Humas Kementrian Perdagangan RI. (2014). Panduan optimalisasi media sosial untuk Kementrian Perdagangan RI. ISBN: 978-602-9179-03-3.

Tirtarahardja, U., \& Sulo, L. (2005). Pengantar pendidikan. Jakarta: Rineka Cipta.

Udin, S. (2008). Inovasi pendidikan. Bandung: Alfabeta.

Uno, H. B. (2010). Teknologi komunikasi dan informasi pembelajaran. Jakarta: Bumi Aksara.

Warti, E. (2016). Pengaruh motivasi belajar siswa terhadap hasil belajar matematika siswa di SD Angkasa 10 Halim Perdana Kusuma Jakarta Timur. Mosharafa: Jurnal Pendidikan Matematika, 5(2), 177-185. 
Wijaya, A. (2018). Kontribusi penggunaan media sosial, lingkungan dan kemandirian belajar terhadap hasil belajar matematika siswa kelas $X$ SMK Muhammadiyah Kartasura. Disertasi tidak Dipublikasikan. Universitas Muhammadiyah Surakarta, Surakarta. 